\title{
Terapi Controller pada Asma
}

Alexander Kam ${ }^{1}$, Fauzar', Roza Kurniati', Zulkarnain Arsyad²

${ }^{1}$ Subbagian Endokrin Metabolik dan Diabetes, Bagian IImu Penyakit Dalam, Fakultas Kedokteran Universitas Andalas/ RSUP Dr. M. Djamil Padang, Indonesia

${ }^{2}$ Subbagian Pulmonologi, Bagian IImu Penyakit Dalam, Fakultas Kedokteran Universitas Andalas/ RSUP Dr. M. Djamil Padang, Indonesia

\section{A B S T R A C T}

\begin{abstract}
Asma, menurut National Heart Lung and Blood Institute (NHBLI) pada tahun 2002, adalah kelainan inflamasi kronik pada saluran nafas yang melibatkan peran banyak sel dan komponen seluler. Tujuan jangka panjang tatalaksana asma adalah untuk mencapai kontrol gejala yang baik dan mempertahankan aktivitas hidup yang normal serta untuk meminimalisir risiko eksaserbasi, penghambatan jalan nafas, dan efek samping. Obat-obatan yang tersedia untuk terapi asma dibagi menjadi pengobatan kontrol jangka panjang atau controller dan pengobatan kerja cepat atau reliever berdasarkan farmakodinamik dan efek klinisnya. Controller adalah terapi yang diberikan untuk menurunkan inflamasi saluran nafas kronik, kontrol gejala, dan menurunkan risiko eksaserbasi dan penurunan fungsi paru. Terdapat beberapa pilihan obat controller asma yang memiliki keuntungan dan kekurangan masing-masing. Pemilihan controller yang tepat akan memberikan kontrol asma yang baik.

Kata kunci: Asma, terapi, controller
\end{abstract}

Asthma, according to the National Heart Lung and Blood Institute (NHBLI) in 2002, is a chronic inflammatory disorder of the airways that involves the role of many cells and cellular components. The long-term goals of asthma management are to achieve good symptom control and maintain normal living activities and to minimize the risk of exacerbations, airway obstruction, and side effects. The drugs available for asthma therapy are divided into long-term control or controller medication and rapid-acting or reliever medication based on their pharmacodynamics and clinical effects. Controller is a therapy given to reduce chronic airway inflammation, control symptoms, and reduce the risk of exacerbations and decreased lung function. There are several asthma controller drug options that have their respective advantages and disadvantages. Selection of the right controller will provide good asthma control.

Keyword: Ashtma, therapy, controller

\section{Apa yang sudah diketahui tentang topik ini?}

Terapi asma dibagi menjadi pengobatan kontrol jangka panjang atau controller dan pengobatan kerja cepat atau reliever berdasarkan farmakodinamik dan efek klinisnya.

\section{Apa yang ditambahkan pada studi ini?}

Terdapat beberapa pilihan obat controller asma yang memiliki keuntungan dan kekurangan masing-masing. Pemilihan controller yang tepat akan memberikan kontrol asma yang baik.

\section{CORRESPONDING AUTHOR}

Phone: 081378583746

E-mail: alexander kam@yahoo.com

\section{ARTICLE INFORMATION}

Received: April 24 ${ }^{\text {th }}, 2021$

Revised: May $4^{\text {th }}, 2021$

Available online: May $27^{\text {th }}, 2021$ 
Pendahuluan

Asma, menurut National Heart Lung and Blood Institute (NHBLI) pada tahun 2002, adalah kelainan inflamasi kronik pada saluran nafas yang melibatkan peran banyak sel dan komponen seluler. Gambaran utama dari asma adalah inflamasi saluran nafas, obstruksi aliran udara yang reversibel, airway hyperresponsiveness (AHR), dan remodeling jaringan. 1,2,3 $^{1}$

Asma, menurut Global Initiative for Asthma (GINA), mengenai sekitar 300 juta penduduk di seluruh dunia. Di Indonesia, prevalensi asma berkisar antara $5-7 \%$. Prevalensi asma dipengaruhi oleh banyak faktor, antara lain jenis kelamin, status atopi, faktor keturunan, dan faktor lingkungan. ${ }^{1,2,3}$

Hingga saat ini, terapi asma tetap berdasarkan protokol pengobatan yang diterbitkan oleh GINA. Terapi asma tersebut terdiri dari reliever dan controller. ${ }^{1,4}$ Tujuan jangka panjang tatalaksana asma adalah untuk mencapai kontrol gejala yang baik dan mempertahankan aktivitas hidup yang normal serta untuk meminimalisir risiko eksaserbasi, penghambatan jalan nafas, dan efek samping. ${ }^{4}$ Melalui tinjauan kepustakaan ini, Penulis mencoba mengulas terapi controller pada asma.

\section{Patogenesis}

Asma dianggap timbul dari mekanisme yang kompleks dari kerentanan genetik dan pengaruh lingkungan, seperti waktu dan dosis alergen serta paparan terhadap infeksi. Walaupun tidak ada gen spesifik atau faktor lingkungan yang khusus menyebabkan asma, predisposisi genetik yang merangsang respon imunoglobulin E (IgE) mukosa lokal, yang dinamakan atopi, menjadi salah satu faktor risiko paling kuat untuk terjadinya asma. ${ }^{1,5}$

Secara klinis, asma muncul sebagai disfungsi fisiologis paru yang ditandai dengan sesak nafas, mengi, dan obstruksi jalan nafas yang bervariasi. Hal ini menjelaskan peningkatan respon jalan nafas yang disebut dengan airway hyperresponsiveness (AHR). Hal tersebut merupakan kelainan fundamental pada asma, walaupun belum ada hubungan yang jelas antara gambaran imunologi dan struktural serta peningkatan respon jalan nafas. Kontriksi bronkiolus yang cepat dan kembali dengan bronkodilator memberikan pemikiran bahwa airway smooth muscle (ASM) terlibat. Penebalan dinding jalan nafas akibat remodeling berhubungan dengan peningkatan AHR. ${ }^{1,6,7}$

\section{Pilihan obat controller pada asma}

Panduan klinis terbaru mengklasifikasikan asma berdasarkan tingkat keparahan dengan menggunakan gejala, fungsi paru, dan penggunaan obat sebagai variabel. Obat-obatan yang tersedia untuk terapi asma dibagi menjadi pengobatan kontrol jangka panjang atau controller dan pengobatan kerja cepat atau reliever berdasarkan farmakodinamik dan efek klinisnya. Controller adalah terapi yang diberikan untuk menurunkan inflamasi saluran nafas kronik, kontrol gejala, dan menurunkan risiko eksaserbasi dan penurunan fungsi paru. Reliever adalah terapi yang diberikan ketika timbul perburukan gejala. ${ }^{3,4}$

Terapi controller adalah terapi untuk mencapai kontrol gejala asma yang baik, mempertahankan aktivitas normal, dan meminimalisir terjadinya eksaserbasi. Terapi ini digunakan secara reguler. Obat controller ini terdiri dari kortikosteroid inhalasi, long-acting $\beta 2$ agonist (LABA), leukotriene receptor antagonist (LTRA), methylxanthin, long-acting muscarinic antagonist (LAMA), dan anti-IgE. 8,9

\section{Kortikosteroid inhalasi}

Kortikosteroid digunakan sebagai terapi pada beberapa kelainan inflamasi pada paru. Kortikosteroid oral pertama kali diperkenalkan sebagai terapi asma pada tahun 1950an dan masih menjadi terapi controller yang paling efektif pada asma. Namun, beberapa efek samping muncul sehingga beberapa penelitian mulai mencari pengobatan yang menggunakan aksi yang bermanfaat pada jalan nafas tanpa adanya efek samping. Pengenalan kortikosteroid inhalasi merevolusi penatalaksanaan pada asma. Karena asma merupakan kelainan inflamasi yang kronis, kortikosteroid inhalasi dipertimbangkan sebagai terapi lini pertama pada asma. ${ }^{3,10}$

Farmakokinetik kortikosteroid inhalasi/ inhaled corticosteroid (ICS) penting dalam hubungannya dengan efek sistemik. Fraksi steroid yang diinhalasi ke paru beraksi secara lokal pada mukosa jalan nafas dan diabsorbsi di permukaan jalan nafas dan alveoli. Dengan demikian, sebagian kecil dosis inhalasi masuk ke sirkulasi.4,10,11 
Kortikosteroid inhalasi direkomendasikan sebagai terapi lini pertama untuk semua pasien asma. George (2012) menyatakan bahwa ICS merupakan terapi controller paling efektif untuk asma, bahkan aman untuk kehamilan. Terapi ini sebaiknya segera dimulai pada pasien yang membutuhkan inhaler agonis $\beta 2$ untuk kontrol gejala. Untuk sebagian besar pasien, ICS sebaiknya diberikan dua kali sehari. Dosis kortikosteroid inhalasi seharusnya merupakan dosis yang minimal untuk mengontrol asma. Dosis ICS dibagi menjadi dosis rendah, sedang, dan tinggi. Dosis ICS ini dijelaskan pada tabel 1.3,10,12

Tabel 1. Dosis ICS4

\begin{tabular}{lccc}
\hline \multirow{2}{*}{ Obat } & \multicolumn{3}{c}{ Dosis harian (mcg) } \\
\cline { 2 - 4 } & Rendah & Sedang & Tinggi \\
\hline $\begin{array}{l}\text { Beclometasone } \\
\text { dipropionate }\end{array}$ & $100-200$ & $200-400$ & $>400$ \\
$\begin{array}{l}\text { Budesonide } \\
\text { Ciclesonide }\end{array}$ & $200-400$ & $400-800$ & $>800$ \\
$\begin{array}{l}\text { Fluticasone } \\
\text { furoate }\end{array}$ & $80-160$ & $160-320$ & $>320$ \\
$\begin{array}{l}\text { Fluticasone } \\
\text { propionate }\end{array}$ & 100 & - & 200 \\
$\begin{array}{l}\text { Mometasone } \\
\text { furoate }\end{array}$ & $110-220$ & $220-440$ & $>440$ \\
$\begin{array}{l}\text { Triamcinolone } \\
\text { acetonide }\end{array}$ & $400-1000$ & $1000-$ & $>2000$ \\
\hline
\end{tabular}

Prednison dan prednisolon merupakan steroid oral yang sering digunakan. Perbaikan klinis dengan steroid oral membutuhkan beberapa hari. Biasanya efek maksimal dicapai dengan dosis 30$40 \mathrm{mg}$ prednison per hari. Dosis pemeliharaan yang sering digunakan adalah 10-15 mg per hari. $3,10,11$

Agonis $\beta 2$ juga memperkuat aksi reseptor glukokortikoid, menyebabkan peningkatan translokasi nuklear reseptor glukokortikoid dan memperkuat ikatan reseptor glukokortikoid pada DNA. Hal ini menyimpulkan bahwa agonis $\beta 2$ dan kortikosteroid memperkuat efek satu sama lain dalam terapi asma. ${ }^{10,13}$

Kortikosteroid inhalasi memiliki efek samping lokal karena deposisi steroid inhalasi pada orofaring. Masalah yang sering ditemukan adalah suara serak dan disfonia akibat atrofi plika vokalis karena deposisi steroid pada laring. Iritasi kerongkongan dan batuk setelah inhalasi sering terjadi pada pemakaian MDI.10,11

\section{Long-acting $\beta 2$ agonist (LABA)}

Agonis $\beta 2$ inhalasi merupakan pilihan bronkodilator pada asma karena obat ini merupakan bronkodilator paling efektif dan memiliki efek samping yang minimal jika digunakan dengan tepat. Pengobatan $\beta 2$ selektif inhalasi memiliki durasi aksi 3-6 jam. Agonis $\beta 2$ agonis kerja panjang inhalasi/ long-acting $\beta 2$ agonist (LABA), seperti salmeterol dan formoterol, memiliki durasi kerja yang lebih panjang sehingga efek bronkodilatasi dan bronkoproteksi bertahan lebih dari 12 jam.3,13

Okupasi reseptor $\beta 2$ oleh agonis menyebabkan aktivasi jalur Gs-adenylyl-cyclase-cAMP-PKA, menghasilkan relaksasi otot polos bronkus. Agonis $\beta$ menyebabkan bronkodilatasi dengan secara langsung merangsang reseptor $\beta 2$ pada otot polos jalan nafas. Secara in vivo, terjadi penurunan resistensi jalan nafas yang cepat.10 Agonis $\beta 2$ bisa menyebabkan bronkodilatasi secara in vivo tidak hanya melalui aksi langsung pada otot polos jalan nafas, namun juga secara tidak langsung dengan menghambat pelepasan mediator dari sel inflamasi dan neurotransmiter bronkokonstriktor dari persarafan jalan nafas. ${ }^{3,4,10}$

Agonis $\beta 2$ kerja panjang inhalasi (LABA), seperti salmeterol, formoterol, dan arformoterol telah terbukti memiliki efek yang baik pada asma. Obat ini memiliki aksi bronkodilator lebih dari 12 jam. Pengobatan ini meningkatkan kontrol asma dengan pemberian dua kali sehari. Belhassen (2016) menyatakan bahwa pemberian LABA dikombinasikan dengan ICS untuk mencapai kontrol gejala asma yang baik. Dosis yang dianjurkan adalah fluticasone $100 \mathrm{mcg}, 250 \mathrm{mcg}$, $500 \mathrm{mcg} /$ salmeterol $50 \mathrm{mcg}$ atau budenoside $80 \mathrm{mcg}, 160 \mathrm{mcg} /$ formoterol $4,5 \mathrm{mcg} .8,10,14,15$

Efek samping dari $\beta 2$ agonis tergantung pada dosis dan rangsangan reseptor $\beta$ ekstrapulmoner. Johnston (2009) menyatakan bahwa efek samping jarang ditemukan pada pemberian dengan inhalasi, namun sering pada pemberian dengan oral atau intravena. Takikardia dan palpitasi disebabkan oleh rangsangan refleks kardiak sekunder terhadap vasodilatasi perifer, dari rangsangan langsung reseptor $\beta 2$ atrium dan kemungkinan juga berasal dari perangsangan reseptor $\beta 1$ miokardial. Hipokalemia, merupakan efek samping yang serius, disebabkan oleh perangsangan reseptor $\beta 2$ untuk memasukkan kalium ke dalam otot rangka. ${ }^{10,14,16}$ 


\section{Leukotriene receptor antagonist (LTRA)}

Terdapat bukti bahwa cysteinyl-leukotriene (LT) diproduksi pada asma dan memiliki efek yang poten terhadap fungsi jalan nafas, termasuk bronkokonstriksi, AHR, eksudasi plasma, sekresi mukus, dan inflamasi eosinofilik. Data ini juga mendukung bahwa dengan menghambat jalur leukotrien dengan leukotriene modifier akan bermanfaat pada terapi asma, menyebabkan pembentukan 5'-lipoxygenase enzyme inhibitor dan beberapa antagonis reseptor cys-LT1, termasuk montelukast, zafirlukast, dan pranlukast. $4,10,17$

Leukotriene receptor antagonist (LTRA) telah diteliti secara intensif pada beberapa studi klinis. LTRA menghambat efek bronkokonstriksi LTD4 yang diinhalasi pada orang normal dan pasien dengan asma. Terapi tersebut juga menghambat bronkokonstriksi yang diinduksi oleh beberapa paparan. Hasil yang sama didapatkan pada inhibitor 5-LO zileuton. Pengobatan ini diberikan secara oral dan bermanfaat pada pemberian jangka panjang. Dosis yang dianjurkan adalah montelukast $10 \mathrm{mg}$, zafirlukast $20 \mathrm{mg} 2$ kali sehari, dan zileuton 400mg 4 kali sehari. $8,10,17$

Pada pasien dengan asma, anti-leukotrien menyebabkan peningkatan yang signifikan pada fungsi paru dan gejala asma, dengan penurunan penggunaan agonis $\beta 2$ kerja pendek. Papierniak (2013) menunjukkan efek bronkodilator, dengan peningkatan pada fungsi paru, yang menyimpulkan bahwa leukotrien berkonstribusi pada bronkokonstriksi pada asma. Namun, antileukotrien masih kurang efektif jika dibandingkan dengan kortikosteroid inhalasi dan tidak bisa dipertimbangkan sebagai terapi lini pertama. Anti-leukotrien diindikasikan sebagai terapi tambahan pada pasien yang tidak terkontrol dengan kortikosteroid inhalasi. Keuntungan penambahannya kecil, ekivalen dengan pelipatgandaan dosis kortikosteroid inhalasi, dan kurang efektif dibandingkan dengan penambahan dengan LABA. ${ }^{10,17}$

Zileuton, zafirlukast, dan montelukast berhubungan dengan disfungsi hati yang jarang terjadi. Oleh karena itu, enzim yang menggambarkan fungsi hati sebaiknya dipantau. Beberapa kasus sindrom Churg-Strauss dihubungkan dengan penggunaan zafirlukast dan montelukast. ${ }^{10,17,18}$

\section{Methylxanthin}

Methylxanthin, seperti teofilin, sudah digunakan untuk terapi asma sejak tahun 1930. Teofilin hingga saat ini masih digunakan secara luas di negara berkembang karena harganya yang tidak mahal. Teofilin menjadi lebih bermanfaat dengan availabilitas plasma cepat dan lepas lambat. Namun, seringnya terjadi efek samping dan efikasi yang relatif rendah dari teofilin menyebabkan penurunan penggunaan obat ini karena agonis $\beta 2$ didapatkan lebih efektif sebagai bronkodilator dan kortikosteroid inhalasi lebih efektif sebagai antiinflamasi. 3,10

Dosis yang dianjurkan adalah $10 \mathrm{mg} / \mathrm{kg}$ berat badan/hari. Untuk terapi jangka panjang, pemberian dua kali sehari dengan dosis $8 \mathrm{mg} / \mathrm{kg} / \mathrm{kali}$ disarankan. Penelitian terbaru menunjukkan, pemberian satu kali teofilin oral memberikan efektivitas yang lebih baik.3,10

Terdapat hubungan yang erat antara peningkatan fungsi jalan nafas dengan konsentrasi teofilin serum. Di bawah $10 \mathrm{mg} / \mathrm{L}$, efek terapeutik dianggap kecil, di atas $20 \mathrm{mg} / \mathrm{L}$ kegunaan teofilin meningkat disertai dengan peningkatan efek samping, sehingga dosis terapeutik dari teofilin adalah 10-20 mg/L. Bahkan di dalam kisaran itu, toksisitas obat masih ditemukan sehingga membuat teofilin menjadi pengobatan yang susah digunakan. Dosis teofilin bervariasi pada pasien yang berbeda karena perbedaan dalam klirens obat. $4,8,10$

Efek samping yang paling sering dari teofilin adalah sakit kepala, mual, dan muntah yang disebabkan oleh inhibisi PDE4. Pada konsentrasi yang lebih tinggi, teofilin menyebabkan aritmia jantung dan kejang. Penggunaan dosis rendah teofilin, dengan target konsentrasi plasma 5-10 $\mathrm{mg} / \mathrm{L}$, mencegah efek samping dan interaksi obat serta menurunkan kepentingan untuk memeriksa ulang konsentrasi plasma. ${ }^{10}$

\section{Long-acting muscarinic antagonist (LAMA)}

Agen ini bersifat antagonis kompetitif ikatan asetilkolin dengan reseptor kolinergik muskarinik. Obat ini akan menghambat efek asetilkolin endogen pada reseptor muskarinik, termasuk efek konstriksi langsung pada otot polos bronkus. Rangsangan pada reseptor tersebut akan mengaktivasi parasimpatis yang menyebabkan bronkokonstriksi. Efek asetilkolin pada sistem respirasi tidak hanya bronkokonstriksi, namun 
juga meningkatkan sekresi trakeobronkial dan merangsang kemoreseptor pada badan karotid dan aorta. 10,19,20

Pada pasien asma, obat antikolinergik kurang efektif dalam hal bronkodilator jika dibandingkan dengan agonis $\beta 2$ dan memberikan proteksi yang lebih rendah terhadap rangsangan bronkus. Obat ini lebih efektif pada pasien asma yang lebih tua karena terjadi pembatasan jalan nafas yang tetap. Obat antikolinergik inhalasi efektif dalam terapi asma akut yang berat, namun tidak lebih efektif daripada agonis $\beta 2$. Namun, pada pengobatan asma, antikolinergik memiliki efek tambahan terhadap agonis $\beta 2$ dan sebaiknya dipertimbangkan jika kontrol asma tidak adekuat dengan agonis $\beta 2$ saja. Antagonis muskarinik sebaiknya dipertimbangkan ketika pengobatan dengan teofilin memberikan efek samping yang hebat atau ketika agonis $\beta 2$ inhalasi menyebabkan tremor yang mengganggu pada orang tua. 10,20

Tiotropium bromida merupakan antikolinergik jangka panjang yang bisa diberikan dengan dosis 18mcg satu kali sehari dengan DPI. Tiotropium berikatan dengan semua subtipe reseptor muskarinik. ${ }^{10,20}$

Antikolinergik inhalasi secara umum diterima dengan baik. Efek samping yang signifikan adalah rasa tidak enak di lidah yang dapat mempengaruhi kepatuhan berobat. Tiotropium bromida menyebabkan rasa kering pada mulut pada $10-15 \%$ pasien, namun biasanya menghilang ketika pengobatan dilanjutkan. 10,19,20

\section{Anti-IgE}

Peningkatan IgE spesifik merupakan gambaran fundamental pada asma alergi. Omalizumab merupakan antibodi monoklonal yang menghambat ikatan IgE terhadap reseptor IgE berafinitas tinggi pada sel mast dan kemudian menghambat aktivasinya oleh alergen. Terapi ini juga menghambat ikatan $\operatorname{IgE}$ dengan reseptor $\operatorname{IgE}$ berafinitas rendah pada sel inflamasi yang lain, seperti limfosit T dan B, makrofag, dan eosinofil, untuk menghambat inflamasi kronik. Omalizumab juga menurunkan kadar IgE dalam sirkulasi.,40,21

Omalizumab digunakan untuk terapi pasien dengan asma berat. Antibodi diberikan secara injeksi subkutan dengan dosis 150-375 mg setiap 2-4 minggu, dan dosisnya ditentukan oleh kadar IgE sirkulasi. Omalizumab menurunkan kebutuhan kortikosteroid oral dan inhalasi daan menurunkan kejadian eksaserbasi. Namun, karena biayanya yang mahal, terapi ini digunakan untuk pasien dengan asma berat yang tidak terkontrol dengan kortikosteroid. Efek samping utam dari omalizumab adalah anafilaktik, yang kejadiannya sangat jarang $(<0,1 \%)^{8,10,21}$

\section{Terapi controller pada asma}

Tujuan jangka panjang tatalaksana asma adalah untuk mencapai kontrol gejala yang baik dan mempertahankan aktivitas hidup yang normal serta untuk meminimalisir risiko eksaserbasi, penghambatan jalan nafas, dan efek samping. Tujuan ini bisa dicapai dengan pemberian terapi controller asma yang tepat. Pada tatalaksana asma berbasis kontrol, tatalaksana farmakologis dan non-farmakologis ditetapkan dalam siklus yang terus menerus yang melibatkan asesmen, terapi, dan peninjauan. Asma diharapkan mengalami perbaikan setelah pengenalan panduan berbasis kontrol ini. Konsep panduan ini adalah pasien diidentifikasi untuk pemberian dan perubahan terapi asma berdasarkan kontrol gejala yang jelek dengan atau tanpa faktor risiko lain seperti fungsi paru yang jelek atau eksaserbasi.3,4

Untuk mendapatkan kontrol asma yang lebih baik, terapi controller yang reguler sebaiknya dimulai segera setelah diagnosis asma ditegakkan. Inisiasi awal kortikosteroid inhalasi pada pasien asma memberikan perbaikan fungsi paru yang signifikan. Pasien yang tidak mendapatkan kortikosteroid inhalasi mengalami eksaserbasi yang berat dengan penurunan fungsi paru. Respon pasien terhadap terapi harus di follow-up dan terapi di-stepped down jika kontrol asma yang baik sudah tercapai.3,4

Sebelum memulai terapi controller, pencatatan gejala dan faktor risiko asma yang dimiliki pasien harus dilakukan. Beberapa faktor harus dipertimbangkan dalam menentukan pilihan terapi. Pasien harus diajarkan cara menggunakan inhaler dengan baik. Selain itu, edukasi kepada pasien agar pasien kontrol secara rutin diperlukan agar tercapai kontrol gejala asma yang baik. $3,4,8$

Setelah memulai terapi controller, respon pasien terhadap terapi harus dinilai setelah dua sampai tiga bulan terapi, atau lebih cepat jika terjadi perburukan gejala. Step-up dan step-down terapi pada asma mengikuti stepwise terapi yang dikeluarkan oleh GINA pada tahun 2021.3,4,8,9 
Begitu terapi asma dimulai, pengambilan keputusan terapi didasarkan pada siklus asesmen, perubahan terapi, dan peninjauan respon. Pengobatan controller disesuaikan dengan pendekatan stepwise untuk mencapai kontrol gejala yang baik dan meminimalisir risiko eksaserbasi, keterbatasan jalan nafas, dan efek samping pengobatan. Setelah kontrol asma yang baik dicapai dan dipertahankan selama 2-3 bulan, terapi bisa diturunkan untuk mendapatkan dosis terapi paling minimal untuk pasien.3,4

Jika pasien masih mengalami tingkat keparahan gejala yang sama dan/ atau eksaserbasi dalam 2-3 bulan pengobatan dengan controller, nilai dan koreksi beberapa masalah yang sering dialami sebelum merubah terapi. Masalah tersebut adalah teknik menggunakan inhaler yang tidak tepat, kepatuhan yang jelek, paparan yang persisten terhadap agen pencetus asma, komorbiditas yang memperburuk gejala pernafasan, dan diagnosis yang salah. Jika tidak ada masalah tersebut pada pasien, dilakukan stepup terapi. $3,4,8$

Step-up terapi bisa dilakukan berupa sustained step up, short-term step up, dan day-to-day adjustment. Sustained step up dilakukan jika pasien gagal mencapai kontrol asma yang adekuat dalam dua hingga tiga bulan terapi. Step-up terapi dilakukan setelah dipastikan tidak ada kesalahan dalam penggunaan alat, kepatuhan berobat masih baik, dan tidak ada faktor risiko seperti merokok. Short-term step up dilakukan dengan meningkatkan dosis ICS sementara selama satu hingga dua minggu. Hal ini dilakukan jika pasien mengalami infeksi virus atau terpapar alergen musiman. Day-to-day adjustment diberikan pada pasien yang mendapatkan kombinasi budesonid/ formoterol atau beklometason/ formoterol sebagai terapi controller dan reliever. Pasien mengatur dosis ICS/ formoterol dari hari ke hari tergantung beratnya gejala asmanya.,3,8

Jika kontrol asma yang baik sudah tercapai dan dipertahankan selama tiga bulan, terapi bisa distepdown tanpa kehilangan kontrol gejala asma. Tujuan step-down terapi adalah untuk mendapatkan terapi efektif yang minimal dan untuk mendorong pasien agar melanjutkan terapi controller yang reguler. Step-down terapi berbeda pada beberapa pasien tergantung terapi yang saat ini sedang dijalani dan faktor risiko yang dimiliki oleh pasien. Terdapat beberapa perbedaan pendapat mengenai waktu yang tepat dan pilihan penurunan terapi yang tepat pada step-down terapi asma. Jika terapi terlalu cepat di-stepdown, risiko eksaserbasi akan meningkat walaupun gejala masih terkontrol. Penghentian terapi ICS berhubungan dengan risiko terjadinya eksaserbasi yang signifikan. Pengurangan dosis ICS yang aman pada banyak pasien adalah 25$50 \%$ dengan interval tiga bulan terapi. Prediktor kontrol yang jelek saat pengurangan dosis adalah airway hyperresponsiveness dan eosinofilia sputum, namun pemeriksaan ini banyak tidak tersedia pada pusat kesehatan. $3,4,8,9$

\section{Simpulan}

Terdapat beberapa pilihan obat controller asma yang memiliki keuntungan dan kekurangan masing-masing. Terapi controller pada asma yang direkomendasikan adalah kortikosteroid inhalasi (ICS) dan kombinasi ICS dengan LABA. Terapi controller pada asma harus di follow-up dan ditentukan apakah diperlukan step-up atau stepdown terapi mengikuti stepwise terapi yang direkomendasikan oleh GINA 20210.

\section{Daftar Pustaka}

1. Mathur SK, Busse WW. The Biology oh Asthma. In Fishman's Pulmonary Diseases and Disorders fourth edition.: McGraw-Hill; 2008.

2. Orihara K, Dil N, Anaparti V, Moqbel R. What's new in asthma pathophysiology and immunopathology? Expert Rev Resp Med. 2010; 4(5).

3. Sundaru H, Sukamto. Asma Bronkial. In Buku Ajar Ilmu Penyakit Dalam. Jakarta: FKUI; $201 \underline{4} 6$.

4. Global Initiative for Asthma. Global Strategy for Asthma Management and Prevention, 2021. Tersedia di www.ginasthma.org

5. Kim YM, Kim YS, Jeon SG, Kim YK. Immunopathogenesis of allergic asthma: more than the Th2 hypothesis. Allergy Asthma Immunol Res. 2013; 5(4).

6. Buc $M$, Dzurilla $M$, Vrlik $M$, Bucova M. Immunopathogenesis of bronchial asthma. Arch Immunol Ther Exp. 2009; 57.

7. Pynn MC, Thornton CA, Davies GA. Asthma pathogenesis. Pulmao RJ. 2012; 21(2).

8. Papadakis M, McPhee S. Current Medical Diagnosis \& Treatment USA: McGraw-Hill; 2016.

9. Boon N, Colledge N, Walker B. Davidson's Principles \& Practice of Medicine. 20th ed. Edinburgh: Elsevier; 2006.

10. Barnes PJ. Pulmonary Pharmacology. In Goodman and Gilman's The Pharmacological Basis of Therapeutics twelfth edition.: McGraw-Hill; 2011.

11. Sobande P, Kercsmar C. Inhaled corticosteroids in asthma management. Respiratory Care. 2008; 53(5).

12. George J, Abramson M, Walker S. Asthma in pregnancy: are inhaled corticosteroids safe? American Journal of Respiratory and Critical Care Medicine. 2012; 185.

Alexander Kam 
13. Salpeter S, Wall A, Buckley N. Long-acting betaagonists with and without inhaled corticosteroids and catastrophic asthma events. The American Journal of Medicine. 2010; 123(4).

14. Xia Y, Kelton C, Xue L, Guo J, Bian B, Wigle P. Safety of long-acting beta agonists and inhaled corticosteroids in children and adolescent with asthma. Therapeutic Advances in Drug Safety. 2013; 4(6).

15. Belhassen M, Langlois C, Laforest L, Dima A, Ginoux $M$, Sadatsafavi $M$, et al. Level of asthma controller therapy before admission to the hospital. J Allergy Clin Immunol. 2016.

16. Johnston S, Edwards M. Mechanisms of adverse effects of beta agonists in asthma. Thorax. 2009; 64(9).

17. Papierniak E, Lowenthal D, Harman E. Novel therapies in asthma: leukotriene antagonists, biologic agents, and beyond. American Journal of Therapuetics. 2013; 20.

18. Montuschi P. Role of leukotrienes and leukotriene modifiers in asthma. Pharmaceuticals. 2010; 3.

19. Smith L. Anticholinergics for patients with asthma? N Engl J Med. 2010; 363(18).

20. Novelli F, Malagrino L, Dente F, Paggiaro P. Efficacy of anticholinergic drugs in asthma. Expert Rev Respir Med. 2012; 6(3).

21. Samitas K, Delimpoura V, Zervas E. Anti-IgE treatment, airway inflammation and remodelling in severe allergic asthma: current knowledge and future prespectives. Eur Respir Rev. 2015; 24. 